\title{
The Law and the "Law": Two Kinds of Legal Space in Late-Qing China
}

La Loi et la «loi »: deux genres d'espace juridique dans la Chine des Qing 法(Law)與治法：晚清中國的两種法律空間

\section{Eric Schluessel}

\section{OpenEdition}

\section{Journals}

Electronic version

URL: http://journals.openedition.org/extremeorient/603

DOI: 10.4000/extremeorient.603

ISBN: 978-2-84292-558-1

ISSN: $2108-7105$

\section{Publisher}

Presses universitaires de Vincennes

\section{Printed version}

Date of publication: 21 November 2016

Number of pages: $39-58$

ISBN: 978-2-84292-556-7

ISSN: 0754-5010

\section{Electronic reference}

Eric Schluessel, "The Law and the "Law": Two Kinds of Legal Space in Late-Qing China », ExtrêmeOrient Extrême-Occident [Online], 40 | 2016, Online since 21 November 2018, connection on 20 April 2019. URL : http://journals.openedition.org/extremeorient/603 ; DOI : 10.4000/extremeorient.603 


\title{
The Law and the "Law": Two Kinds of Legal Space in Late-Qing China
}

\author{
Eric Schluessel
}

The Qing (1636-1911) produced a substantial corpus of codified law that served to routinize many of the imperial government's tasks in maintaining peace and social order, among them the procedure for prosecuting and executing subjects found to have committed capital crimes. ${ }^{1}$ Early in the empire's development, however, certain Ming loyalists articulated an ideological stance against codified law together with their anti-Manchuism. One, Huang Zongxi, wrote of Qing codified law and Chinese codified moralism as opposing varieties of "law" $(f a)$. In the 1840 s, his writings and those of his contemporaries inspired members of the "statecraft" (jingshi) school to articulate a new imaginary of chaos, according to which expanding the geographical reach of moralism at the expense of codified law was necessary to bringing order to the world. I will argue here that the crises of the mid-nineteenth century provided an opportunity for this group to implement policies that carved out a new geography of sovereignty within Qing imperial space. Their idea of sovereignty was predicated on the supremacy of moralism over codified law.

This article concerns a technique of politics and law that provincial Han Chinese elites appropriated in the mid-nineteenth century, "execution on the

1. This article was first presented at the workshop "The Place of the Law in the Late Chinese Empire" in Lyon on 12 May 2015. I am very grateful to Jérôme Bourgon for inviting me to participate and for the comments the paper received. Research was conducted on an International Dissertation Research Fellowship from the Social Sciences Research Council.

In order to conserve space, archival and published documents will be cited according to the following format:

First Historical Archive, Beijing: "FHA (document number) (reign date)." National Palace Museum, Taipei: "NPM (document number) (reign date)." Gongzhong dang Guangxu chao zouzhe (Taibei: Guoli gugong bowuyuan, 19731975): "GZD (volume number) (page number)." 
spot" (jiudi zhengfa). "Execution on the spot," as I will detail further below, entailed a suspension of the statutory procedure for capital punishment: as has been well documented, any execution of a criminal technically needed to be approved by the emperor in Beijing. While amnesty was frequent, and much of the decision-making was certainly handled by the bureaucracy, nevertheless, the power to decide life and death rested symbolically with the sovereign. "Execution on the spot," however, permitted provincial leaders, and even lower-ranking officials or local gentry, to prosecute and execute a criminal and report the matter to Beijing after the fact. Although the practice was popularized during the Taiping crisis (1850-1864), "execution on the spot" was not merely an expedient measure, as its proponents argued. Rather, it became a routine practice in those provinces controlled by the new Han Chinese provincial leaders, notably in the far northwestern region of Xinjiang. Xinjiang was seen as the origin of the practice, and in the late Qing, it became the place where it persisted the longest and had the broadest implementation. Its example will serve to illustrate the basic ideas underlying "execution-onthe-spot" and its purposes.

Studying law from the places it was suspended and negated opens up several useful perspectives, as certain legal theorists and critical legal historians have noted: in the purposeful, or even cynical, suspension of the law, we might see which agents are capable of doing so successfully and perceive more accurately those agents' understandings of what law is or ought to be. ${ }^{2}$ We can see in histories that are often construed in terms of "progress," such as the emergence of modern China, the construction of new internal Others as legitimate targets of state violence. ${ }^{3}$ Our attention is drawn to the instrumentalization of human life construed as intractably chaotic in service of the performance of sovereignty. ${ }^{4}$ Such an approach permits fine-grained comparison between empires on the basis of the spatial and legal imaginaries that inform their governments. ${ }^{5}$ This article will explore these perspectives and offer avenues for further research.

\section{Origins of the Statecraft Legal and Geographical Imaginary}

In order to understand the statecraft imagination of law and space, let us begin with two influential figures from the Ming-Qing transition: Huang Zongxi (1610-1695), whose discussion of law influenced statecraft scholars'

\footnotetext{
2. Schmitt 2005: 97-98.

3. Agamben 2005: 2-5.

4. Mbembe 2003: 11-40.

5. Benton 2010: 6-9.
} 
anti-legal stance, and Wang Fuzhi (1619-1692), whose revival in the 1830s provided a new geographical imaginary of order and chaos.

Huang Zongxi completed the Ming-yi daifang $l u$ in 1663, following many years in armed resistance to the Manchu dynasty. ${ }^{6}$ Huang's goal was to bring the techniques of government from an imagined pre-dynastic past to bear on the problems of his chaotic age. Dynastic, codified law $(f a)$ was a central object of his critique: to Huang, the elaboration of imperial institutions since the Qin (221-206 BCE) had gradually constricted the agency of moral men, encouraged in its place the pursuit of self-interest, and consequently led to the articulation of ever more laws to compensate for emergent immorality in government. Huang dubbed such laws "illegal law" (fei fa zhi fa). In its place, he proposed the revival of "law without law" (wu fa zhi fa), the socio-moral order of humility and humaneness that Neo-Confucians located in the Zhou dynasty. According to Huang, the essence of that order was codified in the Rites of Zhou (Zhouli), and the system of relationships and rituals described therein, the "law of one family, not of a dynasty" (yi jia zhi fa er fei tianxia zhi fa) had engendered a "spirit among men that went beyond the letter of the law" (fa wai zhi yi). Where a contemporary legal scholar might find much to admire in the Qing's accumulation of substatutes, a follower of Huang Zongxi would see the restriction of the genuine force of social ordering, his true "law" $(f a)$ of Confucian moralism.

Wang Fuzhi was also a Ming loyalist who led violent resistance against the Qing. The experience influenced his vision of civilization and barbarism in Chinese history. Wang wrote that the traditional and expansive boundaries of Chinese civilization (wen), as recorded in the Rites of Zhou, had been maintained by popular conformity to the socio-moral norms embodied by the "rites" (li.$^{7}$ Civilization's boundaries later receded during the Song (9601279), when Northern Chinese observance of orthopraxy declined. The center of civilization's essence shifted to the formerly barbarous South, where people had adopted the rites, and in the longer term, this allowed barbarism to prevail in the North, whence the Qing came. Not only would it be possible to restore Chinese civilization by reviving the rites in the North, Wang wrote, it was both necessary and good to impose the rites on Barbarians, force them to adopt Chinese writing and read the Classics, and so transform them. Barbarians, in this view, lived in a state of natural chaos beyond the geographical and cosmological boundaries of a civilizing influence embodied by performance of the rites.

6. Translations from Huang 1993: 4-5, 97-99. Chinese text from Huang 1847: yuanfa.

7. Wiens 1969: 14; Wang 1988: ce 29, 3:16b, 17; v. 4, 1,437-1,438; v. 12, 534. 
The statecraft community around the Yuelu Academy in Changsha, Hunan, revived Wang's writings in the 1830s. ${ }^{8}$ His message and Huang Zongxi's resonated powerfully both with the statecraft group's views of government, political circumstances, and new intellectual interests. While statecraft thought had fallen out of the mainstream discourse of government during the first decades of the Qing, it returned to prominence in the eighteenth century thanks to officials such as Chen Hongmou (1696-1771). During Chen's time as the governor of Yunnan and Shaanxi, he followed Huang Zongxi's prescription for social ills by establishing schools to teach the rites and the Classics to everyone, including the poor and non-Han. ${ }^{9}$ Chen intended to demonstrate that the rites could produce stable, peaceful societies in harmony with moral cosmology, and so did those who later studied at the Yuelu Academy, which Chen himself revived. Statecraft scholars developed a political philosophy centered around a deep-seated "faith in the concept of unfettered bureaucracy as the source of energy for the improvement of government," 10 against impositions from the metropole, and nominally in support of the paternalistic leadership of local moral men.

In short, Qing-era statecraft came to oppose the "illegal law" of statutes and substatutes with the "law without law" of the rites. The statecraft group centered on the Yuelu Academy and Changsha associated the former with the long-term decline of Chinese civilization and with the elaborate Qing government, and the latter with the potential to revive civilization along the minimalist lines of an imagined pre-dynastic golden age. Their program sought to empower provincial and local officials to restructure society to bring it into accordance with the rites and so do away with complex judicial procedures.

\section{Execution-on-the-Spot}

In the mid-nineteenth century, members of the statecraft group had the opportunity to put their anti-legal politics into practice. The next chapter in the history of "execution-on-the-spot" began with a violation of Qing sovereignty on the docks at Canton. Commissioner Lin Zexu (1775-1850), who was granted extensive authority in the matter of the British opium trade, in June 1839 famously destroyed an enormous shipment of opium. Lin also imprisoned a number of foreign opium merchants and requested special authority from

8. Platt 2007: 13-15, 24.

9. Huang 1993: 109; Rowe 2001: 424-25.

10. Polachek 1977: 18 
Beijing to "execute them on the spot." ${ }^{11} \mathrm{He}$ was denied, and instead was punished for his arrogation of authority, which was thought to have sparked off the Opium War, with exile to Ili. Ili, straddling today's Northern Xinjiang and Kazakhstan, was on the opposite end of the Qing empire, and Lin's exile was brief. Nevertheless, he successfully parlayed his experience of the borderlands into intellectual authority within the statecraft discourse. It is clear from his request at Canton that Lin already had "execution on the spot" in mind, but in Xinjiang, he claimed to see it in action.

What Lin witnessed was "immediate execution" (ji xing zhengfa), a longstanding imperial practice of swift capital punishment that had become commonplace in border areas, especially Xinjiang. ${ }^{12}$ From early in the Qing, in situations where banner forces were entering relatively remote circumstances, the emperor would occasionally grant individual commanders the authority to execute violent criminals without undertaking the lengthy process of reportage and review. ${ }^{13}$ This was known as "asking for a royal order to execute immediately" (gongqing wangming ji xing zhengfa). A substatute of the Qing Code dating to 1725 first codifies immediate execution as a punishment not only for banner soldiers who murder their superior officers, but for criminals who have received exile in lieu of execution and subsequently attempt to escape. ${ }^{14}$ This substatute was struck from the Code in 1736, on the argument that it was intended as a temporary measure. However, from 1758 onward, following the conquest of Xinjiang, exile to the region became frequent, and so did escape attempts. "Immediate execution" was restored to the Code in 1761 under the statute "On Exiles Who Commit Further Crimes" (tuliu ren you fan $z u i) .{ }^{15}$ From then through the 1860 s, the majority of "immediate execution" cases noted in the Qing archive were associated with exile to Xinjiang. Despite the name, "immediate execution" was in practice less a matter of shortening the process of investigation and punishment in time and more a technique for keeping executions local: requests for immediate execution argued that, in remote areas, it would be difficult and time-consuming to transport criminals across open and hostile country for interrogation by higher officials, per

11. Zhang 2012: 46-57, 47.

12. Zhang 2009: 44-58.

13. Yao 1901: juan 9, f. 14b.

14. Yao 1901: juan 1, f. 67a.

15. Substatute 8 concerns the punishment of escaped exiles, while a number of others deal with exiles who kill in their places of exile. The dating of Substatute 8 is a little ambiguous, since the available version dates from QL 53 (1788). However, Substatute 17 clearly indicates that it was first established in QL 26 (1761). http://lsc. chineselegalculture.org/eC/HDSLXB/2.1.11.24.0 
statutory procedure. Moreover, executing a criminal in the place where he or she had committed the crime would send a clear message to the local people he or she had harmed: Qing justice was sure and swift. That would prevent conflict from escalating further. Nevertheless, approval was still required from Beijing for many, if not all, cases of immediate execution, meaning that the process could still take several months.

Lin wrote an essay on immediate execution, which he called instead "execution-on-the-spot," in which he depicted it not as a routine practice of imperial government, but as an expedient measure thought up by clever local officials to save time and resources. ${ }^{16}$ The sparseness of the borderland's population, its roads supposedly plagued by bandits, and its poverty of administrative resources, he wrote, meant that criminals could not be processed according to ordinary procedure. "Immediate execution" avoided prolonging investigations and the problem of transporting prisoners across long distances, as they might escape along the road. Moreover, executing a criminal in front of those who knew him or her was an excellent deterrent. Subjects who would not otherwise report a crime would learn to trust their officials, since these could respond quickly and effectively to conflicts in local society. Lin also made a clever linguistic move: "asking for a royal order to execute immediately" became "asking for a royal order to execute on the spot, in order to give a clear warning" (gongqing wangming jiudi zhengfa, yi zhao jiong jie). The latter phrase ("to give a clear warning") was formulaic, but it serves as an index of Lin's influence across the archive, as it would later appear in countless memorials on "execution-on-the-spot."

Lin's essay was well-received among Hunanese Statecraft thinkers, among them Zeng Guofan (1811-1872). In their vision, Xinjiang was not a place where the Qing had succeeded in establishing imperial sovereignty, but rather where Chinese culture and norms had failed to take root. As early as the 1820s, Hunanese statecraft scholars in Changsha had talked about the Western Regions as a blank slate upon which the future of China could be written. It figured in poetry as a desert awaiting the irrigation of civilization, and in proposals concerning economic crisis as a potential place to send what the statecraft clique thought of as the idle lower classes. By moving to the Northwest, it was thought, useless people would transform themselves into productive people, and in turn bring civilization. ${ }^{17}$

The Taiping war provided an opportunity to put this new technique into practice. Under Zeng's leadership, “execution-on-the-spot” became a fixture

16. Lin 1897: j.84, 5 .

17. Chou 1976; Zhang Shiming 2012: 47. 
of wartime government through the Tongzhi reign. In 1853, Zeng Guofan led a number of governors in requesting the suspension of judicial procedure through a series of memorials. One after the other, they memorialized the Court describing a state of siege, in which the chaos and violence of their provinces made it impossible to conduct judicial investigations according to ordinary procedures. ${ }^{18}$ Their demand was the same in every case, to deploy execution-on-the-spot as a "flexible" means to enforce order and achieve stability. "Although it is not in accord with the statute," officials wrote, and would write in hundreds of memorials thereafter, they requested the authority to punish roving groups of armed men, even if those men not actually harmed anyone. The emperor responded individually by approving the plans, and with an edict later that year: "In every province, if local criminals gather in great numbers and wantonly pillage, then after the officials of that place have captured and interrogated them, execute them on the spot." ${ }^{19}$ From this point onward until 1912, "execution-on-the-spot" as practiced in the Qing was not part of the legal code, but of a series of interrelated "flexibility plans" (biantong zhangcheng) proposed by palace memorial and approved by imperial edict. Unlike "immediate execution," "execution-on-the-spot" cases were not reported to Beijing prior to the criminal's death, but rather in packets attached to palace memorials at the end of every year, or sometimes twice a year.

Zeng Guofan removed the need for the emperor to approve every execution. Instead, under his leadership in Hunan, the authority to kill devolved even to non-officials. In his 1853 "Letter to the Upright Gentry and Elders of the Counties of Hunan" (Yu Hunan ge zhouxian gongzheng shenqi shu), he wrote,

I hope that you upright gentry and elders will strictly establish militia regulations, and so tightly wield the transformation of moral customs. Those who are habitually contrary to the law, or who are accustomed to slyly spreading rumors to deceive the masses - report them to the militia commanders and to the clan chiefs, and punish them jointly. If the offense is light, then punish according to family penalties; if heavy, then execute them. Those who flee service as soldiers or braves, and who passing through the villages loot them and bring chaos may be killed without

18. FHA 04-01-01-0917 TZ 13.3.27; FHA 04-01-01-0927-053 TZ 13.3.27; FHA 04-0101-0928-059 GX 1.2.19.

19. 各直省如土匪嘯聚成群, 髼行搶劫, 該地方官於捕獲訊明後, 就地正法. Zhu 1958: 1,319. 
consequence. Those ruffians who raise a mob to seize food, and who go armed to loot the granaries may be killed without consequence..$^{20}$

At this point in the story, it is clear that "execution-on-the-spot" was not meant as a special measure for handling violence in remote places. Rather, it served as a means to handle a different kind of chaos, an internal disorder: with "execution-on-the-spot," Zeng and his clique could conduct a civil war without denying Chinese sovereignty in China proper. Zeng and his allies saw themselves as fighting in an existential struggle against the heterodoxy of the Taiping. Yet, by this point, it is clear that the Hunanese were not fighting for the Manchu rulers of the Qing, but for an idea of China influenced by Huang Zongxi and Wang Fuzhi. This is why Zeng felt he could trust the gentry of Hunan: as Statecraft thinkers had asserted for generations, scholars and gentry were the true moral leaders of society. Now they and their militias held the power of life and death, not the Manchu armies.

Initially, "execution-on-the-spot" was implemented in regions that witnessed hundreds of violent incidents each season, as in fact a war was taking place. The overwhelming majority involved groups of armed men, euphemistically termed "bandits" (zei), whom local authorities were permitted to kill swiftly and without mercy. After the close of the Taiping war, however, recorded rates of violent crime dropped precipitously. In response, governors changed the rationale for retaining the practice. In 1873, permission for "execution-on-thespot" expired in those areas of China proper where governors had requested it, but the edict announcing the end opened up the possibility for the policy to continue indefinitely. ${ }^{21}$ Most governors took advantage of the opportunity to maintain this special judicial power, and their rationales are revealing. The $\mathrm{Hu}-$ Guang Governor-General Li Hanzhang and Hunan Governor Wang Wenshao, like most governors, were primarily concerned with the potential for newlydemobilized soldiers to turn to banditry. Intriguingly, Shanxi Governor Bao Yuanshen argued for the retention of immediate execution in his province by referring to the situation in Xinjiang, which was far from being pacified, but

20. 望公正紳者, 嚴立團規, 力持風化。其有素行不法, 慣為猾賊造言惑眾者, 告 知團總、族長, 公同處罰; 輕則治以家刑, 重則置之死地。其有逃兵逃勇經過 鄉里, 劫掠擾亂者, 格殺勿論; 其有匪徒㿋棍, 聚眾排飯, 持械抄搶者, 格殺 勿論.

21. While I have been unable to find the original edict, it is quoted in each of the memorials requesting renewal for "execution-on-the-spot," including FHA 04-01-01-0927-062 TZ 13.4.1. 
also far from Shanxi. ${ }^{22}$ Bao requested that Shanxi be permitted to continue following the Zhili Flexibility Plan: criminals should be "executed on the spot per military law" (an junlü jiudi zhengfa), regardless of their distance from Taiyuan. Several other governors requested, and were granted, the same permission.

In some places, the practice lingered beyond its wartime use as a means to police what elites perceived to be sources of social instability, particularly sexual impropriety. ${ }^{23}$ The poverty and displacement of the Taiping war apparently led to an increase in wife-selling, forced marriage, and other practices that governors considered to be disruptive to normative familial relations. In 1884, when "execution-on-the-spot" expired again, Hunan and Hubei received further permission to execute traffickers and bandits, even though they were far from the state of crisis of the Taiping era, and there were laws on the books that already criminalized these activities. ${ }^{24}$

\section{Law Without Law in Xinjiang}

As it happens, there was a special connection between policies in Hunan, where Zeng Guofan first implemented "execution-on-the-spot," and those in place in the far Northwestern territory of Xinjiang. In this section, I will show that Xinjiang played a special role in the statecraft group's formation of a spatial imaginary of law and morality, and that its members later implemented a special legal regime in Xinjiang on the basis of that imagination. This consisted of suspending statutory procedure for the prosecution of capital cases in order to enable official activism and the rectification of popular morality. I will argue that Chinese officials imagined Xinjiang to be a more violent and chaotic space than it actually was, that they used this supposed chaos as a pretext to sentence people disproportionately to execution-on-the-spot, and that doing so served to perform Han Chinese sovereignty over this territory and its internal Others. In short, Chinese used execution-on-the-spot to produce a land of "law without law" by suspending Qing codified law in favor of the statecraft principle of official activism.

At the close of the Taiping war, leadership of Zeng Guofan's fighting force, the Xiang Army, was granted to Zuo Zongtang (1812-1885), the new governor-general of Shaanxi and Gansu. Zuo was a statecraft ideologue who

22. FHA 04-01-01-0927-033 TZ 13.7.29.

23. Zhang 2012.

24. Liu (2012): 138-142, 139-140. 
also had a keen interest in the Northwest, particularly Xinjiang. Zuo early on absorbed Gong Zizhen (1792-1841) and Wei Yuan's (1794-1857) schemes for transforming the Inner Asian, Muslim-majority territory into a province on the model of those of China proper. He also met Lin Zexu following the latter's return from Ili and discussed frontier affairs directly with him, including the idea of execution-on-the-spot. Zuo was tasked with taking the Xiang Army across China to retake Shaanxi, Gansu, and eventually Xinjiang, all of which had fallen out of Qing control during the Muslim uprisings (1862-1877). The campaign was an opportunity for Zuo and his small clique of dedicated Hunanese statecraft scholars to implement their ideas.

As the Xiang Army moved into the Northwest, a zone of exception followed them. Everywhere they went, Qing statutory law was suspended in favor of execution-on-the-spot. In Gansu, they successfully maintained executionon-the-spot as a central technique of politics into the early twentieth century, despite orders from the Board of Punishments to return to statutory procedure. ${ }^{25}$ While there was indeed no longer a war on, explained the governor-general in an 1899 memorial, the Hui-as Chinese-speaking Muslims were calledwere prone to violence. Execution-on-the-spot, in his view, meant that officials would waste no time translating depositions or transporting criminals, but could focus instead on reforming the Muslims' morals. Although the codified law could not be replaced, he argued, execution-on-the-spot "had not lost the original spirit of the law" (bu shi ding lü ben yi). Rather, it protected that spirit. However, this "Gansu Flexibility Plan" (Gansu biantong zhangcheng), which later applied in Xinjiang as well, included several other exceptional provisions, including the abrogation of the "rule of avoidance" intended to keep officials from staying in one area. As such, it also permitted the concentration of power in a specific group of leaders, in this case the officers of the Xiang Army, who came from the broader community around the Changsha statecraft clique. ${ }^{26}$

In Xinjiang, execution-on-the-spot was a routine practice of politics from the very beginning. In no case does it appear to have been used to kill enemy combatants. Rather, from the beginning, it was a routine technique of government. The stated reason for execution-on-the-spot was that Xinjiang was persistently difficult to govern, as the non-Han people there were supposedly ignorant of the law. As one of Zuo's clerks put it, the Turki "have ways of punishing but no statutes or substatutes" (you xingfa er wu lüli). ${ }^{27}$ However,

25. Memorial dated GX 25.3.19 in GZD, vol. 12, 712-713.

26. For a study of the "Xiang Army clique" in Gansu, see Zhao 2013. On the same group's activities in Xinjiang, see Schluessel 2016a.

27. Xiao 1895-1897: j. 3 . 
a simple examination of the geographical distribution of capital cases gives the lie to the idea that Muslims were more violent than Han. Analysis of rates of capital crimes per capita in different areas of Xinjiang 1877-1911 show that reported capital crime rates were actually highest in the small, Hanmajority settlements of Xinjiang's North: Karakol-Us (population 3,805, $86 \%$ non-Muslim, 0.21 crimes per 100 people 1877-1911), Changji $(9,801$, $84 \%, 0.122)$, Qitai $(14,590,82 \%, 0.08)$, Suilai $(8,712,79 \%, 0.126)$, Jinghe $(2,285,78 \%, 0.131)$, Qumul $(4,568,73 \%, 0.175)$, and Fukang $(4,634,69 \%$, $0.151)$. The relatively high incidences of violence there correlates roughly with highly mobile populations, as settlements like Jinghe reported a merchant population of over $10 \%$. The next-lowest bracket includes areas with crime rates drastically lower than those of the Han-majority frontier settlements. Barköl $(8,050,100 \%, 0.05)$, Turpan $(71,799,17 \%, 0.026)$, Qarashahr $(24,024$, $21 \%, 0.046)$, and Wensu $(51,285,0.3 \%, 0.047)$. Significantly, all of these medium-crime areas were also in the North, with the exception of Wensu in Aksu Circuit. Barköl, while populated entirely by Han, was exceptional in that its community had been present before the Muslim uprisings and actually survived the conflict into the reconstruction era. Barköl then lost its status as a trading center, and so it had a relatively low sojourning population.

Muslim-majority cities with large populations reported rates of capital crime approaching zero: Shule (Kashgar Old City and Fayżābād, population 304,451, 2\% non-Muslim, 0.008 crimes per 100 people), Shufu (Kashgar New City and adjacent mountainous areas, 173,818, .4\%, 0.017), Yengisar $(116,971,2 \%, 0.021)$, Yarkand (including Pichan, $240,563, .5 \%, 0.011)$, Khotan (197,979, 0\%, 0.013), and Kucha (including Shāhyār, 295,814, 9\%, 0.008), all of them in the South. While each reported more capital crimes cumulatively, the proportion of cases to population was far lower than in Han-majority settlements in the North. Significantly, Kashgar, Yengisar, Yarkand, Khotan, and Kucha all had Islamic legal systems that had been in place for centuries. Despite the disruptions of reconstruction, in which the Hunan Army at first attempted to strip Muslim authorities of power, these courts appear to have persisted. At the same time, local society maintained systems of administration on the local level that dated back centuries, such as the Turko-Mongol system of decimal organization, and could turn to community-elected elders and specialists in irrigation management to resolve many routine disputes. ${ }^{28} \mathrm{In}$ short, it would appear that Muslim areas were, if anything, more stable than Han-majority areas, probably by virtue of possessing longstanding institutions

28. On systems of local administration and dispute resolution, see Bellér-Hann 2008: 179186. 
for dispute resolution that could have prevented conflicts from escalating into violence.

Nor did the overall scale or frequency of violence justify Chinese officials' depictions of Xinjiang as a chaotic space. Metropolitan figures of reported capital punishments 1879-1911 show a maximum of thirty-six incidents in a given year for the entire province, at an average of only eleven to twelve cases per year. This hardly seems to be endemic violence. Interethnic violence, which one might expect to arise from latent hostility towards Chinese on the part of Muslims, accounted for a surprisingly small share of capital crimes. Nevertheless, "execution-on-the-spot" accounted for the majority of reported capital punishments all the way through 1911, thirty-four years after the Muslim uprisings had ended. By the last decade of the Qing, it was used in almost every reported case of capital punishment.

"Execution-on-the-spot" had begun in China proper as a temporary measure for handling exceptional cases of endemic violence. Instead, in Xinjiang, it was employed in a broad range of cases, from a fight over debt between Han Chinese resulting in death ${ }^{29}$ to an incident of graverobbing in which a man stole the clothes from a corpse to keep warm. ${ }^{30}$ The same sorts of crimes were punished either through the statutory process of review or through "executionon-the-spot," seemingly with no logic for choosing the statutory or exceptional method: for example, one husband who killed his wife was executed without approval from Beijing, ${ }^{31}$ while another who did so under nearly identical circumstances was executed according to statute. ${ }^{32}$ One case of frequent robbery in Aksu by a gang of Turki saw only the head of the group punished, and then with a prison sentence and the iron pole. ${ }^{33}$ His followers were all ordered to "reform themselves" (zixin). A number of men were executed immediately for murdering their spouses. ${ }^{34}$ One Hui merchant plotted to kill another for his money and fancy foreign tobacco, and he recruited a Turki to help him. ${ }^{35}$ He was executed immediately, but why were others who committed the same crime not? One Turki killed his landlord over the rent and was immediately exiled (there was an amnesty on that year) ${ }^{36}$ - but another who engaged in an

\footnotetext{
29. FHA 03-7250-056 GX 11.10.27.

30. FHA 03-7584-111 XT 03.05.11.

31. FHA 03-7254-041 GX 13.

32. FHA 03-7309-045 GX 12.08.18.

33. FHA 03-7250-056 GX 11.10.27.

34. NPM 139248-QD, FHA 04-01-26-0096-006 XT 03.05.11.

35. FHA 04-01-26-0096-004 XT 03.05.11.

36. FHA 03-7250-072 GX 11.06.19.
} 
elaborate plot to murder a man and steal his cows was prosecuted according to the usual procedure, all the way off in remote Qarghiliq. ${ }^{37}$

Given that the statecraft clique that ruled Xinjiang was dedicated to empowering local officials, and that their intellectual lineage could be traced back to the pursuit of a society of "law without law," I hypothesize that "execution-on-the-spot" served as a means for Chinese officials to enact that vision of government in place of the centralized sovereignty embodied in the process of review for capital crimes. In part, this practice retained the purpose of "immediate execution" to make examples of criminals swiftly in their local context, demonstrating the efficacy of Qing justice. Yet, just as in China proper, the exceptional measure had gradually become a technique for handling the violent, roving men that elites feared, and then for enforcing morality.

There is one well-documented case of "execution-on-the-spot" in the local archives of Turpan, Xinjiang, and its proceedings support this hypothesis: ${ }^{38}$ on 10 October 1899, a young Hui man named Xi You-nu-zi was leading three donkeys loaded with produce along the highway west of Turpan's New City. About twenty-five miles into his journey across the desert, someone beat Xi You-nu-zi severely about the head, killing him. His eighty-two-sui father Xi Debao and seventy-two-sui mother Ma shi soon after received a letter from a friend who worked in the area and had recognized their son's corpse. Xi Debao reported the matter to the magistrate, and a formal investigation was begun.

The runners soon apprehended a suspect, $\mathrm{Li} \mathrm{Fu}$, a Hui man from Xining. Li's oral deposition changed from document to document as the magistrate's staff worked to establish his culpability, but this editing was normal. ${ }^{39}$ The first version of Li's deposition establishes that he was a migrant laborer who had come from Xining to work in various settlements in both North and South Xinjiang. One day, as he was traveling west of Turpan, he happened to join Xi You-nu-zi. When Li asked Xi for a bite to eat, Xi refused, and so Li became angry, hit $\mathrm{Xi}$ in the head, and knocked him unconscious. As Li was afraid that Xi You-nu-zi would regain consciousness and fight back, he dragged Xi into the desert and beat him to death. Li Fu took Xi's cart, dressed up as a Turki, and sold the contents to a Turki merchant named Ahmad. It was Ahmad who later remembered the suspicious-looking young man and led the pursuit into the desert to find him.

37. GZD 7-648-650 GX 19.02.23.

38. Qingdai Xinjiang dang'an xuanji 2012: vol. 65, 155, 159, 160, 179, 191-193, 212-213, 219-220.

39. I describe this process in Schluessel 2016 b. 
It took less than a week for the Turpan magistrate to request "execution-onthe-spot" from the governor. Up until this point, the investigation had proceeded in a completely ordinary fashion. Now, however, the magistrate emphasized the need for swift action. First, the new version of $\mathrm{Li}$ Fu's deposition, as provided to the provincial judicial commissioner's office, emphasized certain qualities of Li Fu's character: he had no parents, wife, or children, no special skills, and no fixed abode. He wandered from one tobacco farm to another as a day laborer. Li Fu was stealing melons from an unattended shed when Xi Younu-zi walked by, and immediately he thought of murdering Xi You-nu-zi for his money. They walked together for a while, and the kind young Xi You-nu-zi gave Li Fu some buns to eat. When they came to a place where no one would see them, Li Fu reached into his pocket as though to get a bun, but instead pulled out a wooden stick and beat Xi You-nu-zi to death.

This new narrative was key to the Turpan magistrate's argument: the tobacco fields of Xinjiang's North were attracting roving men from the Hui areas of China proper, who were attracted to the better weather in nearby Turpan. These men had no familial attachments - they were "bare sticks" (guanggun), who in the statecraft imagination were the cause of violence and social instability. This one, Li Fu, killed the adopted son of an elderly couple who was their sole source of support. Whereas the Xinjiang government understood family as the foundation of a stable, peaceful society, Li was not only an unstable element himself, he had destroyed the relationships that bound another family together. The magistrate asked to decapitate Li Fu and display his head publicly as a warning to others. The governor approved the execution and closed his reply with Lin Zexu's formula for "execution-on-the-spot": Li would be executed "to give a clear warning." On 4 December 1899, the judicial commissioner's approval arrived in Turpan. The next day, the magistrate's staff and soldiers from the local garrison brought $\mathrm{Li} \mathrm{Fu}$ to a marketplace in the New City and beheaded him.

When news of Li Fu's execution reached Beijing the next summer, his narrative was reduced to a single line alongside nine others: "The Hui $\mathrm{Li} \mathrm{Fu}$ ran across the Turki[!] You-nu-zi leading a donkey loaded with goods along the road, wanted his money, killed him, and hid the body." ${ }^{40}$ From the perspective of Beijing, then, the executed were fairly anonymous, and nothing clearly distinguished them from others who had committed the same crimes and been executed through statutory procedure. If we take a local perspective, however, officials appear to have been concerned primarily with social stability, which they perceived to be threatened by the breakdown of familial relationships as

40. FHA 03-7321-021 GX 26.6.17. 
embodied by "bare sticks" and others who violated those norms. Overall, this hypothesis is supported by the data on "execution-on-the-spot" in Xinjiang: about one-third of the cases involved a wife's murder of her husband. If the Xinjiang officials were primarily concerned with punishing violations of ritual propriety, then this would explain why the graverobber, who harmed no one living, was "executed-on-the-spot." Many other cases involve one or more sojourners, which suggests that magistrates generally viewed men of no fixed abode as sources of disruption who required special punishment. The remainder are mostly robberies that ended in death, however, or petty crimes that appear to have escalated into violent conflicts, and nothing obviously differentiates them from ordinary capital-punishment cases. In order to determine the main motivations behind "execution-on-the-spot" in Xinjiang's local government, further research will be necessary in archives that have not been opened to scholars.

\section{Interpretations}

It is useful to analyze the deployment of "execution-on-the-spot" in terms of critical and colonial legal theory. Schmitt famously wrote that sovereignty rested with those who could declare exceptions to the law, or, more concretely, successfully impose martial law in an otherwise constitutional state. ${ }^{41}$ Agamben sees the same "exception" as a cynical means for nominally democratic governments to undermine rights and freedoms. In both cases, the actor who declares the legal exception claims, legitimately or illegitimately, to be protecting fundamental values that underlie the law. ${ }^{42}$

Schmitt and Agamben's interventions point to the fundamental contradiction in the statecraft group's ideology, which extended to the role of the law: Xinjiang was meant to be transformed from an Inner Asian territory into a province, and so it was placed under the ordinary politico-judicial system of China proper. In order to bring about the fundamental change that would support provincial government, however, the same Chinese officials who imposed their legal system suspended it in the majority of capital cases. In Schmitt's analysis, it would seem that the statecraft clique suspended the law in order to protect and strengthen what they claimed was its foundation: Chinese social norms. In Agamben's terms, they were "protecting" the Qing empire-but what is an empire so "protected?" It would be, as scholars have claimed before with

41. Schmitt 2005: 1 .

42. Agamben 2005: 1-7. 
regard to the statecraft group's influence, an empire undergoing transformation into a nation-state.

However, Schmitt and Agamben are fundamentally concerned with the suspension of the law in modern constitutional states. While the central critical idea of violence's relationship to sovereignty and its instrumentalization in the usurpation of power is useful, there are other phenomena involved that their ideas do not address sufficiently.

It will be useful to compare the late-Qing case with other empires. Achille Mbembe draws our attention to the sovereign's unfettered right to kill in the colonies, where this "necropolitical" principle allows exceptional measures to become routine techniques for the performance of sovereignty through violence. The long afterlife of "execution-on-the-spot" in Xinjiang is reminiscent of the contemporaneous implementation of special legal regimes in imperial borderlands, including the Frontier Crimes Regulation that set up a "bureaucratic authoritarianism" in the Punjab. The Regulation remains law in what is now the Federally-Administered Tribal Areas of Pakistan. ${ }^{43}$ There, and in the Ogaden borderland of Ethiopia, a persistent regime of punishment transformed people into criminalized populations, whom the powerful could continually punish as a way to assert sovereignty. ${ }^{44}$ Xinjiang would appear to be such a space for a late-Qing regime that shifted the locus of sovereignty away from Beijing and into the hands of local officials. Nevertheless, punishing Xinjiang people does not appear to have become a significant part of the broader Chinese discourse of sovereignty.

We can distinguish the pre-Taiping Qing legal system from the post-Taiping legal system: in the former, legal codes produced for different regions reflected the Qing's configuration of multiple subject peoples under a single Manchu aristocratic house. In this sense, the distinction of codified law, including stipulations in the Qing Code of punishments that differ according to status and group membership, reflected the Qing center's organization of the empire. The sovereign had the power not only to kill legitimately, or be merciful, but to distinguish how and under what circumstances which kinds of people would die and how. In this sense, the Qing Code embodied plural imperial sovereignty. The anti-law ideology of the statecraft group drove them instead to carve out a new geography of sovereignty within the empire, bringing civilization to barbarism not through the Qing Code, but through something they believed to be more fundamental: the "law without law" embodied in the ancient rites.

43. Nichols 2013: xi-xviii.

44. Hagmann and Korf 2012: 205-14. 
"Execution-on-the-spot" was meant to aid this process by empowering local Han Chinese officials to act swiftly and with moral certainty.

Benton reminds us that martial law in an imperial setting is not "exceptional" in the way that Agamben means it because the delegation of legal authority is already part of imperial practice..$^{45}$ It would be easy to dismiss "execution-onthe-spot" simply as a manifestation of this delegation. Nevertheless, as I have argued here, the manner of delegation changed suddenly in 1853 with a shift from "immediate execution" as carried out by military authorities to "executionon-the-spot" as practiced by civilian authorities on the model of military law. Moreover, the intent of delegation changed: where the former served to project the imperial sovereign's power into certain kinds of circumstances, the latter shifted the locus of legal authority generally away from the sovereign and into the hands of local officials.

Underlying that shift was a belief in a different kind of law $(f a)$. While I have not been able to discuss their efforts at length here, the Xiang Army clique spent much of the first thirty years of post-uprisings rule in Xinjiang pursuing a civilizing project intended to transform the Muslim family through the imposition of the rites $(l i)$. As a result, Turkic Muslims in Xinjiang perceived in the imposition of the rites something that Huang Zongxi had articulated two centuries earlier: the rites and the statutes were both kinds of "law." ${ }^{46}$ For several decades of Qing history, a significant part of the government emphasized one of these systems at the expense of the other in those places that they deemed chaotic while suspending ordinary judicial procedure: first because of a real state of crisis and endemic violence, then out of fear of violence by roving men, and then in order to control immoral behavior.

45. Benton 2010: 290-291.

46. Schluessel 2016a: Chapter Three. 


\section{BIBLIOGRAPHY}

\section{Archival Sources}

First Historical Archives of China, Beijing.

National Palace Museum, Taipei.

\section{Published Sources}

Agamben, Giorgio (2005). State of Exception. Chicago: University of Chicago Press. BELlÉR-HANn, Ildikó (2008). Community Matters in Xinjiang 1880-1949: Towards a Historical Anthropology of the Uyghur. Leiden: Brill.

BENTON, Lauren (2010). A Search for Sovereignty: Law and Geography in European Empires, 1400-1900. Cambridge: Cambridge University Press.

CHOU, Nailene Josephine (1976). "Frontier Studies and Changing Frontier Administration in Late Ch'ing China: the Case of Sinkiang, 1759-1911.” Ph.D. Diss., University of Washington.

Gongzhong dang Guangxu chao zouzhe 宮中檔光緒朝奏摺 (1973-1975). Taibei: Guoli gugong bowuyuan.

Hagmann, Tobias and Korf, Benedikt (2012). "Agamben in the Ogaden: Violence and Sovereignty in the Ethiopian-Somali Frontier." Political Geography, ${ }^{\circ} 31$ : 205-214.

HUANG, Zongxi 黃宗羲. Ming-yi daifang lu 明夷待訪錄. In Haishanxianguan congshu 海山仙館叢書. Daoguang dingwei (1847).

HuAng, Zongxi (1993). Waiting for the Dawn. Translated by Wm. Theodore DE BARY. New York: Columbia University Press.

LIN, Zexu 林則徐. “Shenming shixi xu huo zuifan jiudi zhengfa pian 審明迤西續獲匪 犯就地正法片.” In GE Shijun, comp. (1897), Huangchao jingshi wen xu bian 皇 朝經世文續編, juan 84, 5 .

LIU, Yanbo 劉彥波 (2012). “Wan Qing liang Hu diqu zhouxian “jiudi zhengfa' shulun 晚清兩湖地區州縣“就地正法”述論.” Jinan xuebao (zhexue shehui kexue ban), 158: $138-142$.

Mbembe, Achille (2003). "Necropolitics.” Public Culture, 15.1: 11-40.

NicHOLS, Robert (ed.) (2013). The Frontier Crimes Regulation: A History in Documents. New York: Oxford University Press.

Platt, Stephen (2007). Provincial Patriots: the Hunanese and Modern China. Cambridge (MA): Harvard University Press.

PolaCHEK, James Montel (1977). "Literati Groups and Literati Politics in Early Nineteenth-Century China," PhD Dissertation. Berkeley: University of California.

Qingdai Xinjiang dang'an xuanji 清代新疆檔案選輯 (2012). Guilin: Guangxi shifan daxue chubanshe.

Rowe, William T. (2001). Saving the World: Chen Hongmou and Elite Consciousness in Eighteenth-Century China. Stanford: Stanford University Press. 
The Law and the "Law": Two Kinds of Legal Space in Late-Qing China

SCHLUESSEL, Eric (2016a). "The Muslim Emperor of China: Everyday Politics in Colonial Xinjiang, 1877-1933,” Ph.D. Diss. Harvard : Harvard University.

SCHLUESSEL, Eric (2016b). "Muslims at the Yamen Gate: Translating Justice in LateQing Xinjiang.” In Ildikó BelléR-Hann, Birgit SCHLYTER, and Jun Sugawara (eds.), Kashgar Revisited. Leiden: Brill.

SCHMITT, Carl (2005). Political Theology: Four Chapters on the Concept of Sovereignty. Chicago: University of Chicago Press.

WANG, Fuzhi 王夫之 (1988). Chunqiu jiashuo 春秋家說. In Chuanshan yishu 船山遺 書. Changsha: Yuelu Chubanshe.

WIENS, Mi-chu (1969). "Anti-Manchu Thought during the Qing." Papers on China 22A: 1-24.

XIAO, Xiong 蕭雄 (1895-1897). Xijiang za shu shi 西疆雜述詩.

YAO, Run 姚潤 (1901). Da Qing lü ji jie fu li 大清律集解附例. Wulin: Wu shi qing lai tang.

ZHANG, Shiming 張世明 (2009). “Qian-Jia shiqi gongqing wangming qipai xianxing zhengfa zhi zhi de kuanyuan zhangchi 乾嘉時期恭請王命旗牌先行正法之制 的寬嚴張弛.” In Nei Menggu shifan daxue xuebao (zhexue shehui kexue ban), 38.4: 44-58.

ZHANG, Shiming (2012). “Qingmo jiudi zhengfa zhidu yanjiu (shang)” 清末就地正法 制度研究 (上). In Zhengfa luncong, 1: 46-57.

ZHAO, Weixi 趙維爾 (2013). Xiangjun jituan yu Xibei Huimin da qiyi zhi shanhou yanjiu: yi Gan Ning Qing diqu wei zhongxin 湘軍集團與西北回民大起義之善 後研究: 以甘寧青地區為中心. Shanghai: Shanghai guji chubanshe.

ZHU, Shoupeng 朱壽朋 (1958). Guangxu chao dong hua lu 光緒朝東華錄. Beijing: Zhonghua shuju.

\section{GLOSSARY}

an junlï jiudi zhengfa 按軍律就地正法

Barköl (Balikun) 巴里坤

Bao Yuanshen 鮑源深

biantong zhangcheng 變通章程

bu shi ding lï ben yi 不適定律本意

Changji 昌吉

Chen Hongmou 陳宏謀

$f a$ 法

fa wai zhi yi 法外之意

fei fa zhifa 非法之法

Fukang 阜康

gongqing wangming ji xing zhengfa 恭請王命既行正法

Gong Zizhen 竟自珍 
Eric Schluessel

guanggun 光棍

Huang Zongxi 黃宗羲

Ili (Yili) 伊犁

Jinghe 精河

jingshi 經世

jiudi zhengfa 就地正法

Karakol-Us (Kuerkala Wusu) 庫爾喀喇烏蘇

Khotan (Hetian) 和田

Kucha (Kuche) 庫車

$l i$ 禮

$\mathrm{Li} \mathrm{Fu}$ 李幅

Li Hanzhang 李瀚章

Lin Zexu 林則徐

Ming-yi daifang $l u$ 明夷待訪錄

Pichan (Bizhan) 䦕展

Qitai 奇台

Qumul (Hami) 哈密

Shāhyār (Shaya) 沙雅

Shufu 疏附

Shule 疏勒

Suilai 綏來

tuliu ren you fan zui 徒流人有犯罪

Wang Fuzhi 王夫之

Wang Wenshao 王文韶

Wei Yuan 魏源

wen 文

Wensu 溫宿

wu fa zhi fa 無法之法

Xi Debao 席得寶

Xining 西寧

Xi You-nu-zi 席由奴子

Yarkand (Shache) 莎車

Yengisar (Yingjisha) 英吉沙

yi jia zhi fa er fei tianxia zhi fa 一家之法而非天下之法

Yu Hunan ge zhouxian gongzheng shenqi shu 於湖南各州縣公正紳者書 zei 賊

Zeng Guofan 曾國藩

Zuo Zongtang 左宗棠 